\title{
IMPACTS OF CREDIT RATING CHANGES ON STOCK RETURNS
}

\author{
by Pham Quynh Chau ${ }^{l}$ - Nguyen Thu Hien ${ }^{l}$
}

\begin{abstract}
This paper studies the impact of credit ratings issued by CIC, a Vietnamese local rating agency, on stock returns of listed companies on the Vietnamese stock exchanges in the period of 2007-2010. The findings of the study confirm the assertions of the previous researches by Holthausen and Leftwich (1986), Hand, Holthausen and Leftwich (1992), Chan and Poor (2008). Specifically, CIC's credit ratings slightly affect the stock prices of the listed firms, an evidence supporting CIC's role and its rating quality to a certain extent. This paper also confirms semi-strong form of the Vietnamese stock market efficiency.
\end{abstract}

Keywords: Credit rating changes, abnormal stock returns

\section{INTRODUCTION}

Credit rating agencies evaluate default risks of securities issuers and issue credit ratings, which is then expected to send reliable information to market participants about financial health and creditworthiness of the issuers. In Vietnam, credit rating agencies services are limited, Credit Information Center (CIC) is the only service provider in this field who produces credit ratings of corporate securities. The CIC, belonging to State Bank of Vietnam, was founded in 2004 and officially associated with Duns \& Bradstreet Pte. Ltd. in 2007. Annually the association (simply called CIC) issues "Credit Rating of Vietnam Public Listed Companies Report", which is published not only in Vietnam but also to Singapore, Hong Kong, Europe and America in Vietnamese and English languages. The CIC focuses on rating the listed companies and publishes reports in the third quarter every year. In recent publication, dated August $26^{\text {th }}$ 2010, $\mathrm{CIC}$ has rated over 400 listed companies on the two Vietnamese stock exchanges, Ho Chi Minh City Stock Exchange and Hanoi Stock Exchange. There are some debates regarding the quality of CIC credit ratings under the concerns of independence and objectivity of the CIC despite no clear evidence. Debates also are going on about the possible impacts of the ratings on stock returns. This research, therefore, sheds lights onto these debates.

Efficiency Market Hypothesis affirms that in an efficient market, stock prices reflect all available information. That is, investors cannot consistently achieve returns in excess of average market returns on a risk-adjusted basis, given the information available at the time the investment is made. As regards to rating announcements, if rating agencies provide market participants with new information, stock prices will respond promptly. Researches by Holthausen and Leftwich (1986) and of Hand, Holthausen and Leftwich (1992) tested the impacts of both Moody's and S\&P's ratings on daily 
stock prices using a large samples of 1,014 rating changes (Holthausen and Leftwich, 1986) and 1,350 rating changes (Handet al,1992) over the 1977-1982 period. These papers investigate potential determinants of the cross-sectional variation in the price to analyze abnormal profits before and after credit rating announcements. Their findings showed the role of rating agencies, in particular the papers provided us with strong evidence that firms downgraded by both Moody's and S\&P's were associated with negative abnormal stock returns in the two - day window beginning the day of press release. Holthausen and Leftwich (1986) also showed a little evidence of abnormal performance on announcement of upgrades. In Hand, et al (1992), the results are analogous to prior conclusions as for bond returns. Along with Hand et al (1992), many papers subsequently confirmed the findings of Holthausen and Leftwich (1986) under different specifications and conditions (Ederington and Goh, 1993, 1999; Hite \& Warga, 1997; Yongtae \& Sandeep, 2003). The effect of credit rating events has also been examined in non-US markets. For instance, the Australian stock market was explored by Lianto and Matolcsy (1995); Creighton, Gower and Richards (2007). Li, Moore and Shin (2006) did a research about Japanese market; for emerging markets, Elayan, Hsu, \& Meyer (2003) studied New Zealand stock market, Chan and Poor (2008) studied China market. In general, these researches found that rating assignments, Credit Watch placements, and rating actions by the international credit raters supply valuable information to investors in these financial markets. Similar results were also detected in for Malaysia, and Thailand markets in the paper of Zhou (2006).

In Vietnam, although credit ratings were introduced several years ago, there is no profile of research on rating announcement impacts on stock returns in Vietnam stock market. This paper, therefore, explores stock return data during the period of 2007 and 2010 to study two possible facts: (1) the certification effect of initial ratings on stock returns, and (2) the signaling effect of rating changes on stock returns.

Dividing the credit ratings into upgrades ratings and downgrades ratings, the results show some evidences about credit ratings that are in conflicts with previous studies in other countries' markets. Event study method is applied to detect information effect of rating announcement on stock returns. Regarding imperfect market condition of Vietnamese stock markets, long post-announcement windows are observed to cover possible lag responses. Three post-event windows are selected, 30-, 60- and 90-day windows starting from rating announcement day (day 0). Setting the event windows not to start before the announcement day is to reflect the limited popularity of CIC report in the Vietnamese market. The CIC report is not popularly published to all market participants but on subscription requests. Most of institutions, especially banks, registered for CIC report since its first publication. Individual investors, however, almost have no access to CIC reports which are considered costly information.

The results show that only negative rating releases have impacts on stock prices at the, 60- and 90-day windows at the significant levels of $10 \%$ and $5 \%$, respectively. The findings confirm the signaling effect of the downgrades credit rating at some extent. Nonetheless, the research fails to detect the evidence of the asymmetric certification impact of initial ratings on stock prices.

\section{TESTABLE HYPOTHESES}

Financial literature has pointed out two major significances of credit ratings, certification effect and rating change effect. Credit ratings certify existing financial 
condition of a firm from an initial rating to market participants such as investors and lenders. Also, credit ratings indicate which way an enterprise's predominant financial power changes through rating changes. A large number of the researches of the credit rating effects on stock returns have been discussed worldwide. Numerous papers have detected evidence that there is the existence of bond and stock abnormal returns following the predicted sign around rating event dates. Evidence of the presence of a certification effect of initial credit ratings and a signalling effect of a rating change have documented in researches of the US market (Holthausen and Leftwich (1986); Hand, Holthausen and Leftwich (1992); Hite \& Warga, 1997; Yongtae \& Sandeep, 2003) and also in nonUS markets (Lianto and Matolcsy (1995); Creighton, Gower and Richards (2007); Li, Moore and Shin (2006); Elayan, Hsu, \& Meyer (2003); Chan and Poor (2008). In details, as regard to the certification effect of credit ratings, the results of these studies indicate that after the rating agency rated a favourable rating to the firm, its stock price responded positive. Moreover, there is no effect on stock returns when the companies are at low ratings.

Attention now is turned to the signalling effect, the findings of most studies offer the significantly statistical evidence that rating downgrades are associated with larger market responses than upgrades, except for some cases, like Creighton et al (2007), in which bond and stock prices react following both positive and negative rating releases. The magnitude of the rating effects, furthermore, is usually fairly slight in comparison with the stock price responses occurring prior to the event dates. An illustration of this is the results of Holthausen and Leftwich (1986) paper in which cumulative average abnormal returns in the US equity market fluctuate around $-20 \%$ in the estimation window of 300 trading days, while the announcement effect just about $-1 \%$. These studies centre on the assumption: information that is positive (negative) for bondholders will be good (bad) news for shareholders, hence, equity prices should react to the news in the same way as bond prices, increasing following improvement (up-letters) and declining following deterioration (down-letters). Goh and Ederington (1993), nonetheless, recommend that not all downgrades will result in negative abnormal returns. The given explanation is that in circumstances where a decline in a bond rating may not reflect any assessments of a firm's performance (earnings or sales), but may reflect management decisions to benefit one class of claimants which transfer bondholders' wealth to shareholders, so a downgrade should be a good news for shareholders.

The frameworks of these papers emanate from the two reasons: Firstly, the rating agencies are seen as the powerful information intermediaries since they take full advantages of their mechanism for the access to corporate inside information such as the issuer's takeover, expansion, new products, patents, debt issuance plans, which are maintained in strict confidence. Therefore, stock market reacts promptly when credit ratings release as a surprise. Secondly, if firms have incentive to announce positive information about their prospects but play their negative information down, markets, then, will base on third-parties like rating agencies for an objective analysis, hence credit rating deterioration will be more newsworthy.

The testable hypotheses of our work are mainly relied on the certification and signalling effects of local credit ratings in Vietnam. Like China, the CIC credit ratings have attracted much criticism from a large 
number of local investors and seen as no merit. They provide arguments that credit ratings issued by the CIC are useless and optimistic because the agency is influenced by political and business ties rather than underlying economic fundamentals of the issuer. In essence, the political and business environment in Vietnam creates a generous rating culture to attract more businesses, even though those debates have not been documented any academically statistics evidence. Furthermore, our credit rating sector is at the start-up stage, therefore, the quality of local credit rating agencies may be far behind their Western and the US counterparts.

Based on the findings in the literature and the practical side, the study hypothesizes that if the rating announcements do not contain news, or just reflect public information available, our expectation is that little or no market response to the ratings released. On the other hand, if rating changes are based on future projections of firms' credit quality, or imply hints of inside information, it is foreseen that there will be a market reaction. In the case, market can respond in various directions, we expect there is a significant difference in market responses to upgrades and downgrades; furthermore downgrades will be associated with negative abnormal stock returns.

\section{DATA AND METHODOLOGY}

The methodology for testing announcement effects of credit ratings relies on event study method with annual credit rating announcements during period from 2007 to 2010 are the events. During this period, there are four credit rating announcements, and therefore three credit rating changes.

The credit ratings are collected from the CIC annual publications, namely "Credit Rating of Vietnam Public Listed Companies" and CIC database warehouse. The CIC annual presses provide information containing rating types, current ratings and the previous years' ratings, the industry classifications of rated firms, and brief legal and financial information about each listed firms in the CIC annual sample. The announcement dates of rating changes are gathered from the CIC website, and also from some electronic economic news expresses such as VnEconomy. Apart from the rating data source, daily stock prices are obtained from data stream of the Golden Bridge Investment Consultant Joint Stock Company (GBIC) through its website. Stock prices of negotiated deals are omitted because these transactions are deregulated and access to these data is impossible.

Stocks to be included in the sample must be rated and reported in CIC's annual publications, and be listed and have historical stock prices for the full period $(-150,90$ days) around the announcement date (date 0 , denoted $t_{\mathrm{o}}$ ). Rating changes are defined and studied as shown in Table 1.

\section{Table 1. Event definition}

\begin{tabular}{l|l|l|}
\hline Event type & Definition & Examples \\
\hline $\begin{array}{l}\text { Upgrade } \\
\text { Downgrade }\end{array}$ & $\begin{array}{l}\text { The announcement of a positive change in rating } \quad \mathrm{CCC} \rightarrow \mathrm{B} / \mathrm{BB} / \mathrm{A} / \mathrm{AA} \\
\text { The announcement of a negative change in rating }\end{array} \quad \mathrm{AAA} \rightarrow \mathrm{AA} / \mathrm{A} / \mathrm{BBB} / \mathrm{C}$ \\
Investment grade & $\begin{array}{l}\text { A rating moves to investment grade and above } \\
\text { (BBB is the lowest investment grade) }\end{array}$ \\
$\begin{array}{l}\text { Non-investment } \\
\text { grade }\end{array}$ & $\begin{array}{l}\text { A rating down from investment grade and below } \\
\text { (BB is the highest non-investment grade) }\end{array}$ \\
\hline
\end{tabular}


The initial sample consists of 1,750 observations of year - firm credit ratings over the time period of 2007 and 2010. After dropping unqualified observations based on the selection criteria, the final sample comprises of 527 rating changes, including 268 upgrades and 259 downgrades in the observed period, including 138 firms on HOSE and 178 on HNX.

For each announcement day, price changes is observed in three post-event windows, $\mathrm{T}_{1}=30$ days, $\mathrm{T}_{2}=60$ days and $\mathrm{T}_{3}=90$ days. The choice of the event window is relied on the buy and hold strategy of investors. More important reason of selecting these windows is to obtain a full aspect of how the market reacts to CIC's rating releases given immature market conditions in a young and developing financial market like Vietnam. The long event windows, consequently, are used to cover possible lagged reactions of the market.

This paper adopts the market model in calculating daily stock returns of sample companies. Because the sample companies are listed on two separate stock exchanges, for each stock the stock return is regressed on the corresponding stock exchange indexes. For instance, a HSX stocks' returns are regressed on the HSX index returns.

$$
\begin{aligned}
& \mathrm{R}_{\mathrm{it}}=\alpha+\left(\beta_{\mathrm{i}}\right) \mathrm{R}_{\mathrm{mt}}+\varepsilon_{\mathrm{it}} \\
& \mathrm{E}\left\{\varepsilon_{\mathrm{it}}\right\}=0 \operatorname{var}\left\{\varepsilon_{\mathrm{it}}\right\}=\sigma^{2} \varepsilon_{\mathrm{i}}
\end{aligned}
$$

In this model, $\mathrm{R}_{\mathrm{mt}}, \mathrm{R}_{\mathrm{it}}$ are the return on the market portfolio, and the period- $\mathrm{t}$ return on security $i$ respectively, $\varepsilon_{i t}$ is the time period $t$ disturbance term indicating the unsystematic risk component known as residual. $\alpha_{i} \beta_{i}$ and $\sigma^{2} \varepsilon_{i}$ are the parameters of the market model. In turn, $\alpha$ is the intercept coefficient of regression models using the
Ordinary least squares (OLS), and $\beta$ is the $\mathrm{X}$-variable coefficient.

The abnormal return is the actual expost return of the security over the event window minus the normal return of the firm over the event window (MacKinlay, 1997). For firm $i$ and event date $t$, the abnormal return is:

$$
\mathrm{AR}_{\mathrm{it}}=\mathrm{R}_{\mathrm{it}}-\mathrm{E}\left(\mathrm{R}_{\mathrm{it}} \mathrm{X}_{\mathrm{t}}\right)
$$

where $\mathrm{AR}_{\mathrm{it}}, \mathrm{R}_{\mathrm{it}}$ and $\mathrm{E}\left(\mathrm{R}_{\mathrm{it}} \mathrm{X}_{\mathrm{t}}\right)$ are the is conditioning information for the normal abnormal return, actual, and normal return model, and will be measured by returns respectively for time period $t . \mathrm{X}_{\mathrm{t}}$ Equation 3 .

$$
\text { ARit }=\varepsilon_{\text {it }}=R_{\text {it }}-E\left(\alpha_{i}\right)-E\left[\left(\beta_{i}\right) R_{m t}\right]
$$

The $\mathrm{AR}_{\mathrm{i}}$ are averaged across the $\mathrm{N}_{\mathrm{i}}$ firms in the sample for each event day $\mathrm{t}$ :

$$
\mathrm{AARt}=\frac{1}{N} \sum_{i=1}^{n} A R i t
$$

The average abnormal returns make overall inferences for each period as (AARt), then, are aggregated in order to the following equation:

$$
\text { CARt1, } \mathrm{t} 2=\sum_{t=t 1}^{t 2} A A R t
$$


The test statistic for the significance of abnormal return means between the two groups equals to the ratio of $\mathrm{AAR}$ to its standard deviation. The purpose of the test is to examine the certification effect of ratings on stock prices.

$$
\mathrm{t}=\mathrm{AAR}_{\mathrm{t}} / \mathrm{s}\left(\mathrm{AAR}_{\mathrm{t}}\right)
$$

The next step is to explore determinants of stock returns around announcement days. This paper explores the signalling effect of the changes in rating grades, and also the effect of the economic distress over the researched period on the excess stock returns using crosssectional regression analysis applied in Holthausen and Leftwich (1986) and Goh

and Edington (1993) papers. To explain cross-sectional variation in abnormal stock returns during the event window, the multivariate regressions are employed and separately tested for downgrades and upgrades. The variables of Equation 7 are derived from the paper sited above and the relevant literature. The OLS multivariate regressions equation is in the below form:

$$
\mathrm{CAR}_{\mathrm{it}}=\beta_{\mathrm{o}}+\beta_{2}\left(\# \mathrm{GRD}_{\mathrm{it}}\right)+\beta_{3}\left(\mathrm{INV} \mathrm{GRD}_{\mathrm{it}}\right)+\beta_{3}\left(\mathrm{CHANGE}_{1}\right)+\beta_{4}\left(\mathrm{CHANGE}_{2}\right)
$$

In which, the dependent and independent variables are designated as follows:

$\mathrm{CAR}_{\mathrm{it}}=$ Abnormal performance for stock $\mathrm{i}$ in the window day 0 to day +90 . The dependent variable is percentage and denoted by CAR in the estimated regression equations.

In this OLS regression, the corporate credit rating change (\#GRD), hence, is the central independent variable as reviewed in the literature. The variable \#GRD, which is the first priority, is the number of grades changed and is calculated as new rating less old rating. This is a cardinal variable measured on the scale of 9 (for rating AAA) to 1 (for rating $\mathrm{C}$ ). The abnormal stock return is expected to depend positively on the number of grades changed by the variable measure. Hence, if downgrades (upgrades) associated with negative (positive) abnormal returns, the coefficient on the variable should be positive (negative).

The second one is the dummy variable INV GRD and set equal to one

for the rating change moving the firm into investment grade or above or out of, zero otherwise. This variable is put into the test to examine whether rating changes which move listed firms into or out of investment grade are associated with a higher reaction of excess return. The predicted sign of the coefficient on variable INV GRD should be positive for upgrades and negative for downgrades.

In addition, the two dummy variables are added to the equation for distinguishing among year-changes, CHANGE1 designates change of 2007 over 2006 and CHANGE2 denoted for change of 2008 over 2007 . The coefficients on these variables are predicted positive. The regression variables are summarized in Table 2. 
Table 2. The predicted signs of the independent variables on stock return regression

\begin{tabular}{llll}
\hline Concepts & Variables & Measures & Expected sign \\
\hline $\begin{array}{l}\text { Cumulative } \\
\text { abnormal return }\end{array}$ & CAR & Aggregated daily abnormal returns & Dependent variable \\
$\begin{array}{l}\text { Credit rating } \\
\text { changes }\end{array}$ & \#GRD & New rating less Old rating & $\begin{array}{l}(+) \text { for down-letters } \\
\text { Or }(-) \text { up-letters }\end{array}$ \\
$\begin{array}{l}\text { Investment grade } \\
\text { INV GRD }\end{array}$ & $\begin{array}{l}\text { Dummy variable equal to one if the rating } \\
\text { change moves a firm into investment grade } \\
\text { (BBB and above) from below or out of in- }{ }^{-}(-) \text {for downgrades } \\
\text { vestment grade from above, zero otherwise }\end{array}$ \\
$\begin{array}{l}\text { The second } \\
\text { change 2007/08 }\end{array}$ & CHANGE2 & $\begin{array}{l}\text { Dummy variable equal to one if the rating } \\
\text { change between 2007and 2008 }\end{array}$ \\
\hline
\end{tabular}

\section{RESULTS}

\subsection{Impact of rating change announcements}

Overall results in Table 3 show no evidence that rating announcements have any significant impacts on stock returns. Signs of the upgrades and downgrades on stock returns are not consistent. Both upgrades and downgrades create non- significant abnormal returns in 30-day event window; however create negative non-significant abnormal returns in 60and 90-day event windows. Also, there is no significant difference between upgrades and downgrades impacts on stock returns in all windows. The evidence fails to propose a certification effect of CIC credit rating changes on common stock prices in the sampled period.

Table 3. Equity market reactions to the announcements of CIC rating assignments

\begin{tabular}{llll}
\hline & $\begin{array}{l}\text { 30 day excess returns } \\
\text { (CAR30) }\end{array}$ & $\begin{array}{l}\text { 60 day excess returns } \\
\text { (CAR60) }\end{array}$ & $\begin{array}{l}90 \text { day excess returns } \\
\text { (CAR90) }\end{array}$ \\
\hline Upgrades & .026141 & -.031988 & -.053221 \\
Downgrades & .021768 & -.020601 & -.057872 \\
Mean Difference & .0043728 & -.0113866 & .0046512 \\
t-value & .207 & -.340 & .120 \\
Sig. (2-tailed) & .836 & .734 & .904 \\
All rated firms & .024016 & -.026667 & -.055717 \\
\hline
\end{tabular}




\subsection{Explanatory ability of credit ratings changes}

The study next turns to test the potential explanatory ability of credit rating changes on stock returns. The regression equation (7) is conducted individually for each group of upgrades and downgrades, respectively the results of these assumptions and hypothesis tests are presented in Table 4.

Table 4. Determinants of stock abnormal returns

\begin{tabular}{|c|c|c|c|c|c|c|}
\hline & \multicolumn{3}{|c|}{ UPGRADES abnormal stock returns } & \multicolumn{3}{|c|}{ DOWNGRADES abnormal stock returns } \\
\hline & 30-day & 60-day & 90-day & 30-day & 60-day & 90-day \\
\hline & 7.1 & 7.2 & 7.3 & 7.4 & 7.5 & 7.6 \\
\hline Intercept & -0.0528 & $-0.1863 * * *$ & $-0.23298 * * *$ & $-0.0877 * * *$ & $-0.2220 * * *$ & $-0.2525 * * *$ \\
\hline \# GRD & 0.0237 & 0.05108 & 0.049941 & 0.016463 & $0.05014^{*}$ & $0.07075 * *$ \\
\hline INV_GRD & $-0.0406^{*}$ & $-0.1131 * * *$ & $-0.1252 * * *$ & -0.020764 & 0.009676 & 0.01519 \\
\hline CHANGE1 & $0.0473 * * *$ & $0.1488 * *$ & $0.2094 * *$ & $0.1351 * * *$ & $0.3420 * * *$ & $0.412 * * *$ \\
\hline CHANGE2 & 0.23285 & $0.416988 * * *$ & $0.4306^{* * *}$ & $0.2696^{* * *}$ & $0.5066^{* * *}$ & $0.530 * * *$ \\
\hline $\mathrm{R}^{2}$ & 0.195 & 0.24155 & 0.1836 & 0.231935 & 0.3668 & 0.343833 \\
\hline Adjusted $\mathrm{R}^{2}$ & 0.1829 & 0.2300 & 0.1710 & 0.219839 & 0.3568 & 0.333500 \\
\hline F-statistic & 15.939 & 20.940 & 14.666 & 19.175 & 36.783 & 33.274 \\
\hline $\begin{array}{lccc}P & r & o & b \\
\text { (F-statistic) } & \end{array}$ & 0.000 & 0.000 & 0.000 & 0.000 & 0.000 & 0.000 \\
\hline DW value & 1.70204 & 1.5842 & 1.5452 & 1.6974 & 1.7577 & 1.7419 \\
\hline White (Prob.F) & 0.000265 & 0.394029 & 0.690873 & 0.186273 & 0.181179 & 0.491112 \\
\hline
\end{tabular}

$(*),(* *),(* * *)$. Denoted significance at the $10 \%, 5 \%$, and $1 \%$ levels, respectively.

$D W$ is denoted the value of Durbin - Watson test.

According to the table 4, all DW values were near 2. As a rule of thumb, hence, there is little evidence of positive serial correlation in the residuals. The following essential assumption test is homoscedasticity using White Heteroskedasticity Test. Most of the p-values are greater than $\alpha=0.05$, hence Homoscedasticity Test results strongly reject the existence of heteroskedasticity in the residuals of these other estimated equations, excluding the first equation (equation 7.1) of the up-group at p-value of 0.000265 that suggests the presence of hetero in the residuals of this equation. Moreover, $\mathrm{R}^{2}$ values of the all equations were not high or extraordinary, just around nearly $20 \%$ and $36.68 \%$. Initially, overall regression fit can be claimed due to some following convincing proofs. Firstly, the F- statistic values of the all estimated equations are associated strongly with the significance of $\alpha=5 \%$, (at all $p$-values $=0.0000)$, therefore this implies that the regressions totally fit since all of the regression coefficients are different from zero excluding intercepts. In addition, the 
explanatory powers, $\mathrm{R}^{2}$, fluctuate around $18.36 \%$ and $24.155 \%$ at upgrades, while at the downgrades these coefficients have a higher score between $23.19 \%$ and $36.68 \%$. In other words, the evidence proves that all independent variables selected can appropriately explain less than $40 \%$ of the dependent variables, CAR.

Regarding findings from regression analysis, a striking point is that the information about the financial improvement of the listed firms has the slightly impact on their stock price to a certain extent. This incredible outcome is strongly contrary to the results of the mean tests presented earlier. The evidence is that for downgrades most of the coefficients on the key independent variable, \#GRD, in the all three equations were statistically significant excluding the first downgrade subgroup of CAR30. In this study, efforts to explore an immediate market-response to rating events if the announcements are informative for investors have been failed because there was no market reaction to the 30-day periods tested because the coefficient on the variable \#GRD of the equation 7.1 and 7.4 were insignificant (t-values of 0.4359 and 0.4094 , respectively). At this point, our study completely differs from the findings in comparison to Chan and Poor (2008) in which they found the variable Grade is highly significant at $5 \%$ and $1 \%$ around the narrow announcement dates, $(-1,0$ and $-1,+1)$ and market participants react more strongly to the investmentgrade ratings than the initial speculativegrade ratings. This provides the solid proof for determining statistically the fact that CIC role and its credit rating releases have been narrowing, hence market reaction has not been immediately response to the announcement dates. Nonetheless, as for the two others of the down subgroups, CAR60 and CAR90, the estimated coefficients of the two observed groups on \#GRD are trustful around 2, t-statistic values of 1.8467 and 2.3272 , respectively. Therefore, they are significant at the $10 \%$ and $5 \%$ levels. Consistent with the predicted signs, these estimated coefficients are positive. As the measurement of the variable \#GRD formed in the previous part, in which this variable is positive (negative) for upgrades (downgrade) because it is calculated as new rating less old rating. Therefore, if the up (down) letters are associated with positive (negative) abnormal returns of common stocks, the coefficients on \#GRD should be predicted negative (positive). The coefficient on \#GRD offers that the marginal effect on abnormal returns of the CIC rating changes for each grade is 0.05014 for 60 day-period and 0.07075 for 90 day-period. As for this point, the findings of this research are analogous to the main results of the many prior papers, such as Holthausen and Leftwich (1985), Lianto and Matolcsy (1995), and Creighton et all (2007) and confirms the incremental information content of credit down-letters. Furthermore, the paper provides proofs for the conclusion that even in the weak form of the small and emerging capital market like Vietnam, the influence of credit rating changes on common stock prices would be acknowledged. On the contrary to the findings of the previous researches in small and emerging markets like New Zealand and Spain which were analysed by Elayan et all (2003) and Fernandez and Romero (2006), this research fails to identify market responses to the credit rating revisions for upgrades. This is an appealing result because many arguments and evidence have been proved that in the emerging market, the dimensions of the market response occur in various ways against developed markets, but in the case of Vietnam, it seems to be inappropriate. 
In addition, the paper, in contradiction to the paper of Holthausen and Leftwich (1985) just mentioned, offers salient results. It is evident that the coefficients on variable INV GRD of the all down letters are insignificant, whereas with regards to the upgrades all of them were considerably significant at t-statistic values much less than zero. The variable INV GRD is comprised to test whether rating changes are connected with larger stock price responses. Hence, for improvements (deteriorations), the coefficients on INV GRD are expected positive (negative). The signs of them, however, did not follow the prediction. However, analogous findings are explored by Chan and Poor (2008), and this result implies that as for the Vietnamese case, market participants react more strongly to the stocks moved into the investmentgrade rating $(\mathrm{BBB})$ and above than the speculative-grade ratings. This response may emanate from the proposal that the firms will take actions transferring wealth from lenders to stockholders to improve their credit letter (Goh and Ederington, 1993, 1999). Put another way, the firms have promoted their credit rating letters, but these upgrades have been thanks to anticipated declines in leverage by issuing stocks for funding and in that case market responses are unlikely to react.

Contrary to the two prior variables, most estimated coefficients of the two controlling variables, CHANGE1 and CHANGE2, are statistically significant, excluding the equation 7.1 for upgrade CAR30. These results suggest that the time of the press releases have influences on CARs surrounding initial announcements. In sum, based on the researched results analysed earlier, somewhat the paper has been succeeded in supporting the hypothesis the incremental information of credit rating revisions affect common stock prices in Vietnam stock exchanges during the researched period. This research, furthermore, lays the initial foundation for the event study with regards to the effect of credit ratings on equity returns in Vietnam.

\section{CONCLUSION}

The study examines the incremental information content of the CIC rating events on stock returns from 2007 to the early 2011. This study is carried out using the sample of 527 rating change observations involving 317 rated firms listed on both HOSE and HNX. Simultaneously, the event study framework and the multivariate OLS regression models are principally applied into analysing the explanatory power of each selected independent variable on the cumulative abnormal stock return. The research fails to find significant difference between abnormal stock returns of upgrades and downgrade credit rating announcements around the event window. In contrast, the paper obtained significant findings that the CIC rating revisions have impacts on the stock prices of the sampled firms. It is obvious that with an examination of market reaction to rating events annually announced by the CIC over the researched period, the evidence indicates that rating announcements have been informative for downgrades at the 60- and 90-day windows, which is consistent with Holthausen and Leftwich (1986), Hand at all (1992), but for both upgrades and downgrades the study failed to explore the signal of the prompt market response to the narrow event window of the 0,30 days, in contrast with Chan and Poor (2008) with respect to China market.

To some extent, the study provides convincing evidence for adding to the literature on the incremental information of credit ratings on common stock returns with regard to the Vietnamese market. It is confident to claim that this is the first study depicting the dawn of this issue in 
Vietnam based on the CIC credit ratings and stock market data. On the theoretical side, the findings of this paper are expected to support latter researches in exploring more evidences of CIC rating impacts on common stock returns. On the practical side, the main innovative findings of the work are beneficial to not only the CIC but also related market participants including the regulators, investors, and stock issuers as well. Regarding investors, especially individuals, the study offers convincing evidence for changing their awareness of the CIC role and its rating quality. Moreover, the findings suggest some new insights for investors to understand stock price behaviour in response to rating changes. Therefore these participants should facilitate their portfolio and also the investment decisions. Attention now is turned to the central party, CIC, who plays a key role in providing market participants with transparent information as an independent rating agency. In contrary to developed capital markets, in this study, the findings indicate that CIC rating events did not seem to be anticipated, but investors did not promptly integrate the information compared to earnings announcements, or the introduction of the new regulation on the economy and capital market. There is a need for further improvement in broadly promoting awareness of the rating quality. From the new findings of the paper, it cannot be denied that local listed firms should pay much concern on their credit ratings because it is a reliable financial indicator in the stock market. It is important to consider the implication for regulators. Authorities such as Ministry of Finance and State Securities Commission of Vietnam should rely on credit ratings to screen and manipulate the capital markets.

\section{REFERENCES}

1. Andayani, W., Pusposari, D., \&Sukoharsono, E. G. (2010). Earnings quality and bond rating: Empirical evidence in Indonesia. Journal of International Finance and Economics. 10(4).

2. Barron, M.J., Clare, A.D., \& Thomas, S.H. (1997). The effect of bond rating changes and new ratings on UK stock returns. Journal of Business Finance and Accounting, 24(3): 497-509.

3. Bhattacharya, U., Daouk, H., Jorgenson, B. \&Kehr, Carl -Heinrich. (2000). When an event is not an event: the curious case of an emerging market. Journal of Financial Economics, 55, 69-101.

4. Bodie, Z., Kane, A., \& Marcus, A, J. (2009).Investment, $8^{\text {th }}$ edition. New York, NY: McGraw -Hill International Edition.

5. Chan, K.C., \& Poor, W.P.H. (2008). An empirical examination of the informational content of credit ratings in China. Journal, 61(7):790-797. doi:10.1016/j. jbusres.2007.08.001.

6. Clauretie, T., \& Wansley, J. (1985). The impact of credit watch placement on equity returns and bond prices. Journal of Financial Research, 8(4): 31-42.

7. Creighton, A., Gower, L., \& Richards, A.J. (2007). The impact of rating changes in Australian financial markets, Pacific-Basin Finance Journal, 15(1): 1-17. doi:10.1016/j.pacfin.2006.04.003. 
8. Deddouche, D., \& Richards, A. (2003). Bank rating changes and bank stock returns: puzzling evidence from emerging markets. Journal of Emerging Market Finance, 2(3): 337-363. doi: 10.1177/097265270300200304.

9. Ederington, L.H., \&Goh, J.C. (1993). Is a bond rating downgrade bad news, good news, or no news for stockholders? The Journal of Finance, 48(5): 2001-2008.

10. Ederington, L.H., \&Goh, J.C. (1999).Cross-sectional variation in the stock market reaction to bond rating changes. The Quarterly Review of Economics and Finance, 39(1): 101-112.

11. Elayan, F.A., Hsu, W.H., \& Meyer, T.O. (2003). The informational content of credit rating announcement for share prices in a small market. Journal of Economics and Finance, 27(3): 337-356. Retrieved from ProQuest Central.

12. Fernández, M.D., \& Romero, A. P. (2007). Bond rating changes and stock returns: evidence from the Spanish stock market. Spanish Economics Review 9, 79-103. doi: 10.1007/s10108-006-9020-0.

13. Hand, J.R., Holthausen, R.W., \&Leftwich, R.W. (1992). The effect of bond rating agency announcements on bond and stock prices. The Journal of Finance, 47(2): 733-752.

14. Hite, G., \&Warga, A. (1997).The effect of bond-rating changes on bond price performance.Financial Analysts Journal, 53(3): 35-51.

15. Holthausen, R.W., \&Leftwich, R. W. (1986). The effect of bond rating changes on common stock prices. Journal of Financial Economics, 17(1): 57-89.

16. Li, J., Shin, Y.S., \& Moore, W.T. (2006). Reactions of Japanese markets to changes in credit ratings by global and local agencies. Journal, 30(3): 1007-1021. doi:10.1016/j.jbankfin.2005.05.026.

17. Lianto, T., \&Matolcsy, Z.P. (1995). The incremental information content of bond rating revisions: the Australian evidence. The Journal of Banking and Finance, 19(5): 891-902. SSDI 0378 - 4266(94)00082 - 4.

18. MacKinlay, A.C. (1997). Event studies in Economics and Finance. Journal of Economics Literature, 35(1): 13-39.

19. Pinches, G.E., \& Singleton, J.C. (1978). The adjustment of stock prices to bond rating changes. The Journal of Finance, 33(1): 29-44.

20. SBV's CIC,\& Dun \& Bradstreet PTE LTD. (2009). Credit ratings of Vietnam Public Listed Companies, Hanoi, HN: Labour Publishing House.

21.SBV's CIC,\& Dun \& Bradstreet PTE LTD. (2010). Credit ratings of Vietnam Public Listed Companies, Hanoi, HN: Labour Publishing House.

22. Yongtae, K., \&Sandeep, N. (2003). Why do stock prices react to bond rating downgrades?. Managerial Finance, 29(11): 93-107. Retrieved from ProQuest Database. Zhou, Chen. (2006). Information value of credit ratings in Asia ExJapan markets. Dissertation and Theses Collection. Paper 23.Retrieved from http:// ink.library.smu.edu.sg/etd coll/23. 